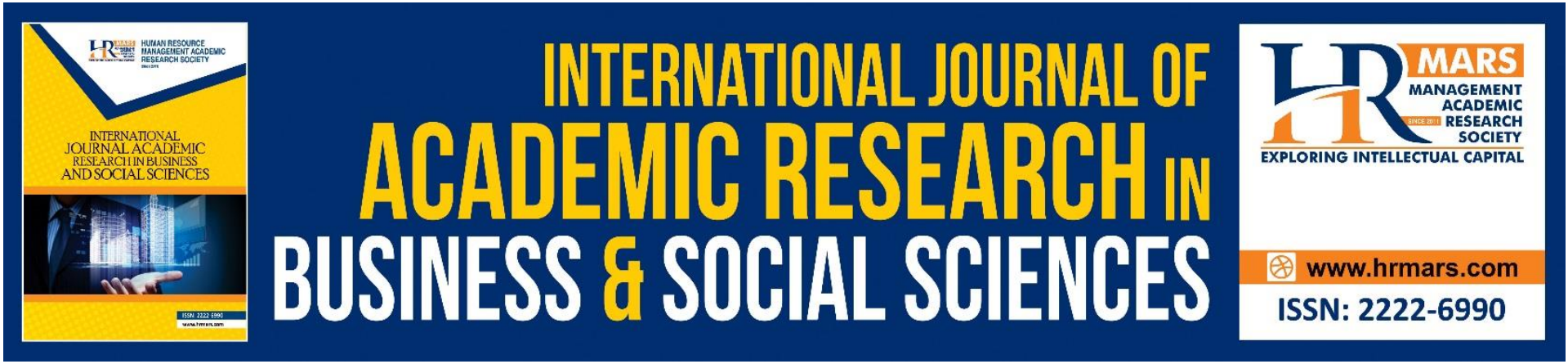

\title{
An Investigative Study of Cognitive and Metacognitive Paraphrasing Strategies in ESL Writing
}

Noor Hanim Rahmat

To Link this Article: http://dx.doi.org/10.6007/IJARBSS/v11-i3/8919

DOI:10.6007/IJARBSS/v11-i3/8919

Received: 13 January 2021, Revised: 09 February 2021, Accepted: 23 February 2021

Published Online: 08 March 2021

In-Text Citation: (Rahmat, 2021)

To Cite this Article: Rahmat, N. H. (2021). An Investigative Study of Cognitive and Metacognitive Paraphrasing Strategies in ESL Writing. International Journal of Academic Research in Business and Social Sciences, 11(3), 76-87.

Copyright: @ 2021 The Author(s)

Published by Human Resource Management Academic Research Society (www.hrmars.com)

This article is published under the Creative Commons Attribution (CC BY 4.0) license. Anyone may reproduce, distribute, translate and create derivative works of this article (for both commercial and non-commercial purposes), subject to full attribution to the original publication and authors. The full terms of this license may be seen

at: http://creativecommons.org/licences/by/4.0/legalcode

Vol. 11, No. 3, 2021, Pg. 76 - 87

http://hrmars.com/index.php/pages/detail/IJARBSS

JOURNAL HOMEPAGE

Full Terms \& Conditions of access and use can be found at http://hrmars.com/index.php/pages/detail/publication-ethics 


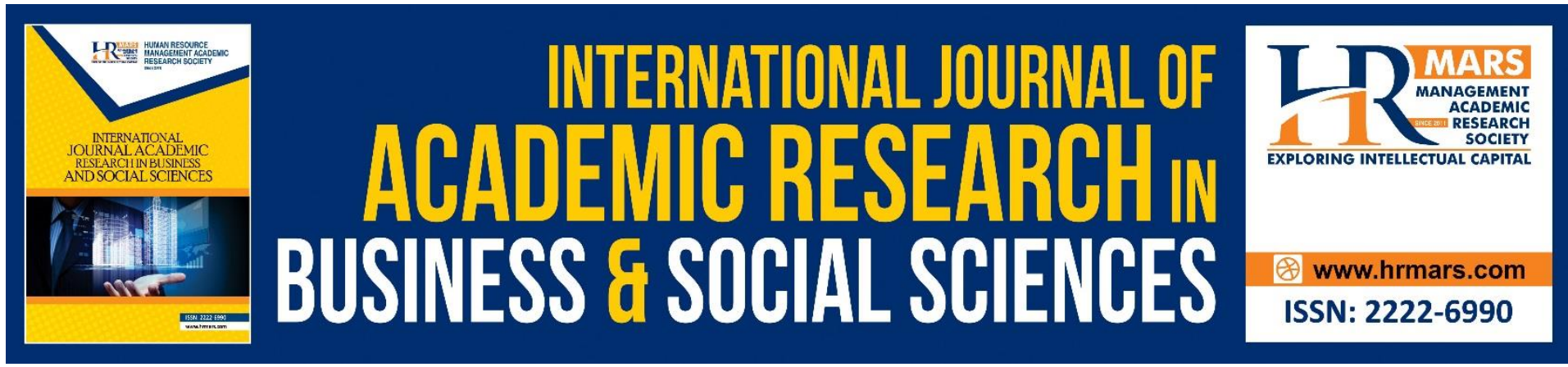

\title{
An Investigative Study of Cognitive and Metacognitive Paraphrasing Strategies in ESL Writing
}

\author{
Noor Hanim Rahmat \\ Akademi Pengajian Bahasa, Universiti Teknologi MARA, Malaysia
}

\begin{abstract}
Paraphrasing is not an easy task as it involves the writer using many levels of knowledge. A writer needs to use both reading and writing skills to write. He/she needs to go through the stages of before, during and after writing processes in order to reach the final draft. Paraphrasing is not an easy task as it requires the writer to use both cognitive and metacognitive strategies. This study explores the aspects of cognitive and metacognitive strategies that is used by the writer to paraphrase. A survey is use to elicit responses from purposely random chose ESL writers who went through a semester of academic writing class. Findings revealed that writers consciously and unconsciously use components of cognitive and metacognitive strategies to paraphrase. The results of this study bear interesting implications in the teaching and learning of academic writing for ESL learners.
\end{abstract}

Keywords: Paraphrasing, Writer, Writing Process, Cognitive, Metacognitive.

\section{Introduction}

\section{Background of Study}

Of all the communication skills (reading, writing, listening and speaking), writing is considered one of the more difficult skills to master. Communication skills is a two-way interaction between the sender and receiver. Unlike oral communication, the sender (writer) may not have direct contact with receiver (reader). Writers are in conversation with the readers through the text they wrote (Haeza \& Rahmat, 2020). So, when the writer lacks writing skills, the communication between the writer and the reader is affected. What are the problems in writing? According to Al-Khasawneh (2010), writers face problems with vocabulary size and also sentence structure. What caused these problems? The problems in academic writing can be caused by three difficulties namely (Rahmat, 2019) and Larenas, Leiva, and Navarrete (2017); (a) Linguistics Difficulty, (b) Cognitive Difficulty and (c) Cognitive ability. Linguistic ability refers to the aspects such as grammar, vocabulary, language use and choice of sentences. Cognitive difficult stems from the writer not knowing what the reader knows (do not know). Physiology difficulty can be achieved when writers are skillful in areas such as spelling, punctuation, capitalization and even paragraphing. In addition to that, Al Badi (2015) and Abdulkareem (2013) found that many academic writers lacked skills such as referencing, citations and paraphrasing. 
The study by Na \& Mai (2017) investigated the paraphrasing ability of EFL learners. The study also explored the challenges faced by students when paraphrasing. Findings showed that that participants frequently paraphrased using synonyms. They rarely changed syntactic structures. Paraphrasing is a difficult skill to master. Many academic writers think they are paraphrasing ; but, in actual fact, they are merely summarising. Some encountered languagerelated difficulties when attempting to paraphrase, such as inadequate understanding of the source text and the lack of vocabulary to use when paraphrasing.

Paraphrasing is an important skill for academic writers because using this skill can help writers to avoid plagiarism. According to Keck (2006) and Gusparia (2017), the knowledge of paraphrasing skills in academic writers helps them make sense of the text before they focus on information needed to be transferred into their writing. Failure to use good paraphrasing skills would force the writers to "copy-paste" or plagiarize the information form the original text into their written work. Hence, this study is done to investigate what strategies academic writers use when they paraphrase. Specifically, this objective of this study is find out how learners use cognitive and metacognitive strategies when they paraphrase. This study seeks to find the answers to the following research questions;

\subsubsection{How is paraphrasing considered a cognitive strategy? \\ 1.1.2 How is paraphrasing considered a metacognitive strategy?}

\section{Literature Review \\ Introduction \\ Problems with Paraphrasing}

It is reported that academic writers often have problems with paraphrasing. To begin with, academic writing is difficult because the writer needs to use appropriate words and phrases, as well as to generate ideas (Aripin \& Rahmat, 2021). In addition to that, according to Hayuningrum and Yulia (2017), academic writers sometimes a variety of paraphrasing mistakes. Some writers include the content from an original text; however, they sometimes forget to document the evidence. Next, writers sometimes tend to include too much of the original information form the original text. Redundant information often create more confusion to the readers. On the other hand, some either misread the original information or leave out important details from the original text. There are some writers who would also expand or narrow the meaning in the original text. Finally, some make the mistake of substituting inappropriate synonyms or even summarising the information instead of paraphrasing it.

Why do academic writers make mistakes with paraphrasing? According to Gilmore (2008), some writers have low reading comprehension to begin with. The failure to understand the original text may create mistakes in paraphrasing. Writers who are working in a second /foreign language may also make mistake sin paraphrasing.

\section{Paraphrasing Strategies of Writers}

Paraphrasing involves both reading and writing skills. The writer begins the paraphrasing activity by reading and then ends with writing. With reference to Figure 1 . The writer begins with problem analysis. This is the first stage where the writer reads the chosen/assigned material and analyse whether the information is suitable for the academic writing. The writer then goes back to the academic writing and makes decisions as how he/she can add 
information to the content of the writing (solving content knowledge), Next, the writer then improves on the structure (solving discourse knowledge) of the write-up. The final stage is called problem translation because this is the stage where the writer makes decisions on what to add /delete from the draft.

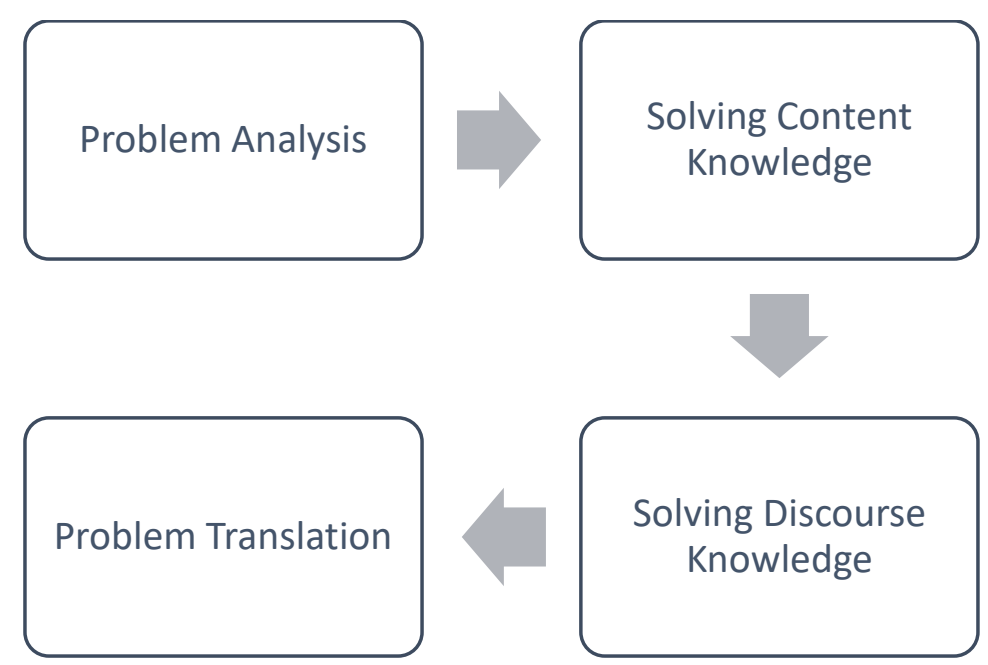

Figure 1- Read-to-Write Model (source: Rahmat, 2022)

Strategies in Academic Writing

There are some common strategies that writers perform in their academic writing.

According to $\mathrm{Mu}(2005)$, writers may use strategies like rhetorical, meta-cognitive, and cognitive.

\section{Rhetorical Strategies}

Rhetorical strategies are the strategies that writers use to present the ideas for his/her writing. The writer may use strategies such as the organization of an essay, the use of the mother tongue to organize paragraphs and sentences, and the presentation of ideas in writing conventions acceptable to native speakers of that language.

\section{Meta-cognitive Strategies}

Metacognitive strategies refer to the writers' global skills. The strategies also include the writers' trying to increase their knowledge about cognition so as to help them raise their self-awareness, direct their own learning, and monitor their own progress.

\section{Cognitive Strategies}

According to Sethuraman and Radhakrishnan (2020), cognitive strategies help students to process, transform, and create information in order to assist writers to use language effectively in the knowledge acquisition process.

\section{Past Studies}

The perception of writers towards paraphrasing influences the way they (the writers) write. The study by Khrismawan and Widiati (2013) explores the perception of students about paraphrasing and their cognitive and meta-cognitive processes in paraphrasing. This mixed mode study investigated four subjects' ability to perform paraphrasing activities. Data was collected from verbal reports, a survey and an interview. Findings revealed that the paraphrasing activities performed showed that cognitive and meta-cognitive strategies were 
used to paraphrase. In addition to that the results of the verbal report showed that the subjects used 21 known cognitive and 7 meta-cognitive strategies.

It is interesting to observe that academic writers are aware of the importance of paraphrasing skills and teaching strategies can help writers paraphrase. The study by Akbar (2020) explores the paraphrasing skills of six undergraduates in their academic writing. The findings of this qualitative study revealed that among the six students, three are able to paraphrase while the other three produced almost the same copy from the original text. In addition to that, the study by Sedhu, Lee \& Choy (2013) explored the teaching strategies for paraphrasing skills. Data is collected from students' weekly journals on their feelings towards paraphrasing. Findings showed that students performed better at summary writing when the teachers adopted content-driven teaching strategies.

Next, there are also past studies that revealed that writers used a variety of paraphrasing strategies. According to Keck (2006), paraphrasing is an important skill for academic writers and he suggested that the teaching of paraphrasing could help students from copying chunks from the original text. His study analysed 79 first language and 74 second language academic writers. Keck's (2006) study revealed that the paraphrases can be categorized into four major Paraphrase Types: (a) Near Copy, (b) Minimal Revision, (c) Moderate Revision, and (d) Substantial Revision. The study then compared the L1 and L2 writers' use of these Paraphrase Types within their summaries. It was found that, while both groups used about five paraphrases per summary, L2 writers used significantly more Near Copies than L1 writers. Conversely, the summaries of L1 writers contained significantly more Moderate and Substantial Revisions than those of the L2 writers. Another study by Bejos (2009) also looked at paraphrasing strategies of academic writers. In this case study, The student used expository texts from a textbook adoption materials. Instruction was based on scaffolded dialogue that cued the student to attend to and paraphrase various aspects. The findings revealed that several factors contributed to the complexity of the task for the student. 


\section{Methodology \\ Conceptual Framework}

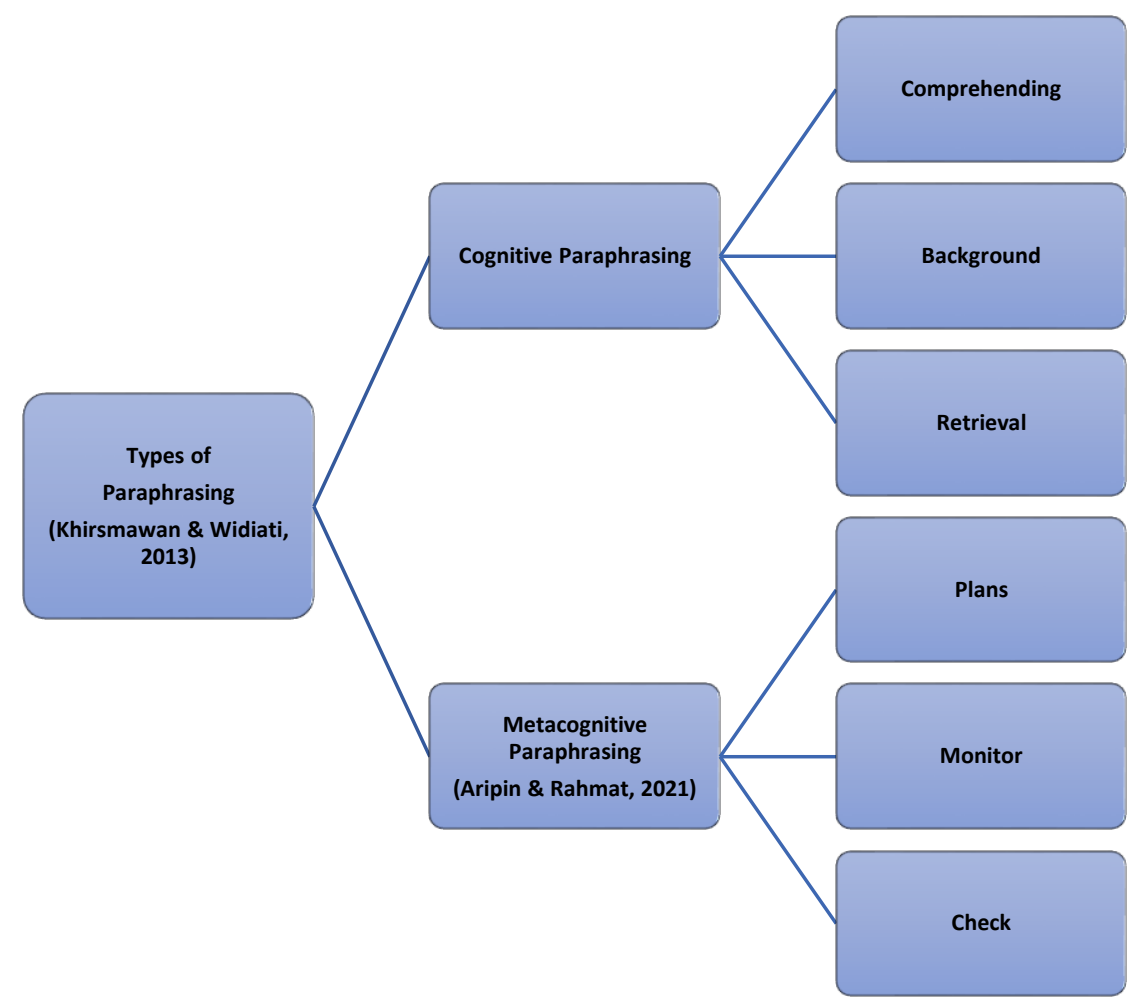

Figure 2- Types of Paraphrasing

(Source: Khirsmawan \& Widiati, 2013)

The conceptual framework of the study is adapted from types of paraphrasing strategies by Khirsmawan \& Widiati (2013) and Aripin \& Rahmat (2021). During paraphrasing, the academic writer (consciously or unconsciously) goes through two levels of activity. The first is cognitive paraphrasing where the writer starts by comprehending the original text. In order to understand better, the writer needs to have some background knowledge of the content of the original text. Next, the writer retrieves his or her background and content knowledge to make sense of the original text. The second strategy is metacognitive strategy. During the paraphrasing stage, the writer makes plans on what or how to write his/her written text. $\mathrm{He} / \mathrm{She}$ then monitor the content of the text by going back and forth from the original text to his/her own text. Finally, the writer checks his/her work before submission.

\section{Research Design}

This quantitative study is done to explore the how academic writers perceive the paraphrasing process. Paraphrasing skills are considered complex as it involves the use of both cognitive and metacognitive strategies. 31 students were chosen to be part of the purposive sample in the study. The instrument used in this study is a survey. The 5 -likert scale survey is adapted from the list of Cognitive and Metacognitive paraphrasing strategies (Khirsmawan \& Widiati, 2013). Reliability analysis of the instrument reveal Cronbach alpha of 0.920 thus showing a high reliability (Table 1 ). 


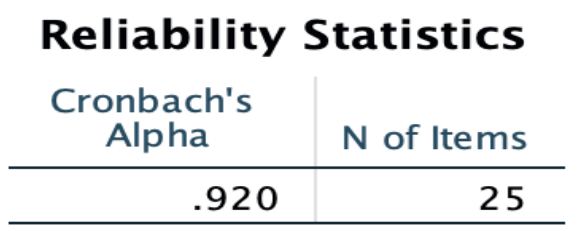

Table 1- Reliability Statistics for the Study

\section{Data Collection and Data Analysis}

Data collected from the survey is then analysed using SPSS version 26 . The analysis is presented based on the frequency of occurrences of the responses and presented in the form mean scores.

\section{Findings}

Introduction

This section discusses findings of study by answering the two research questions;

1.1.3 How is paraphrasing considered a cognitive strategy?

1.1.4 How is paraphrasing considered a metacognitive strategy?

Cognitive

According to Khirsmawan \& Widiati( 2013), cognitive strategies includes sub-strategies such as (a) comprehending, (b) background and (c) retrieval.

\subsubsection{Comprehending}

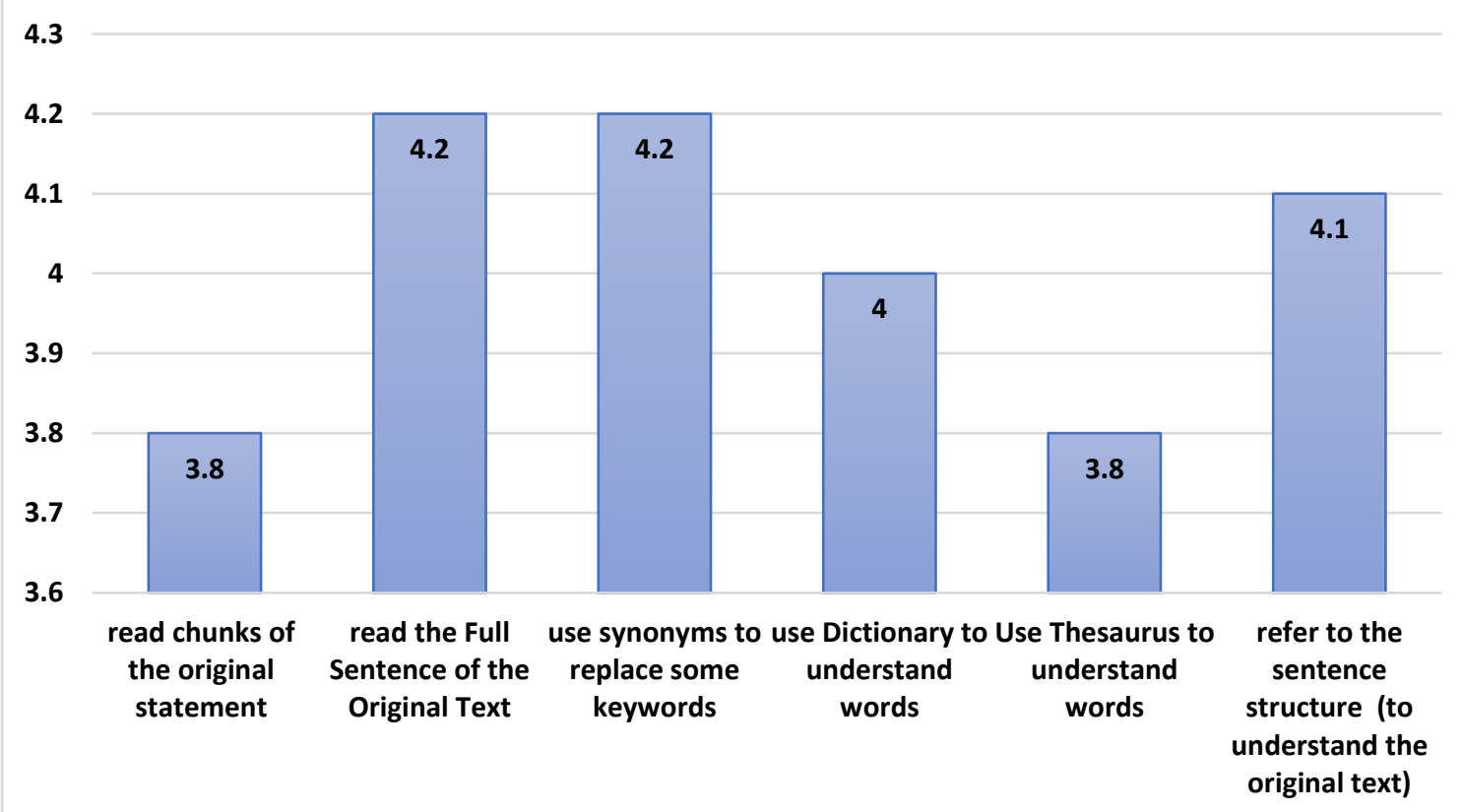

Figure 3- Bar Chart showing frequency for Comprehending

Figure 3 shows the mean score for comprehending. Respondents reported highest mean (4.2) for reading "the full sentence of the original text" and "use synonyms to replace some 
keywords". They also reported that they referred "to the sentence structure" to ease understanding (4.1).

\subsubsection{Background}

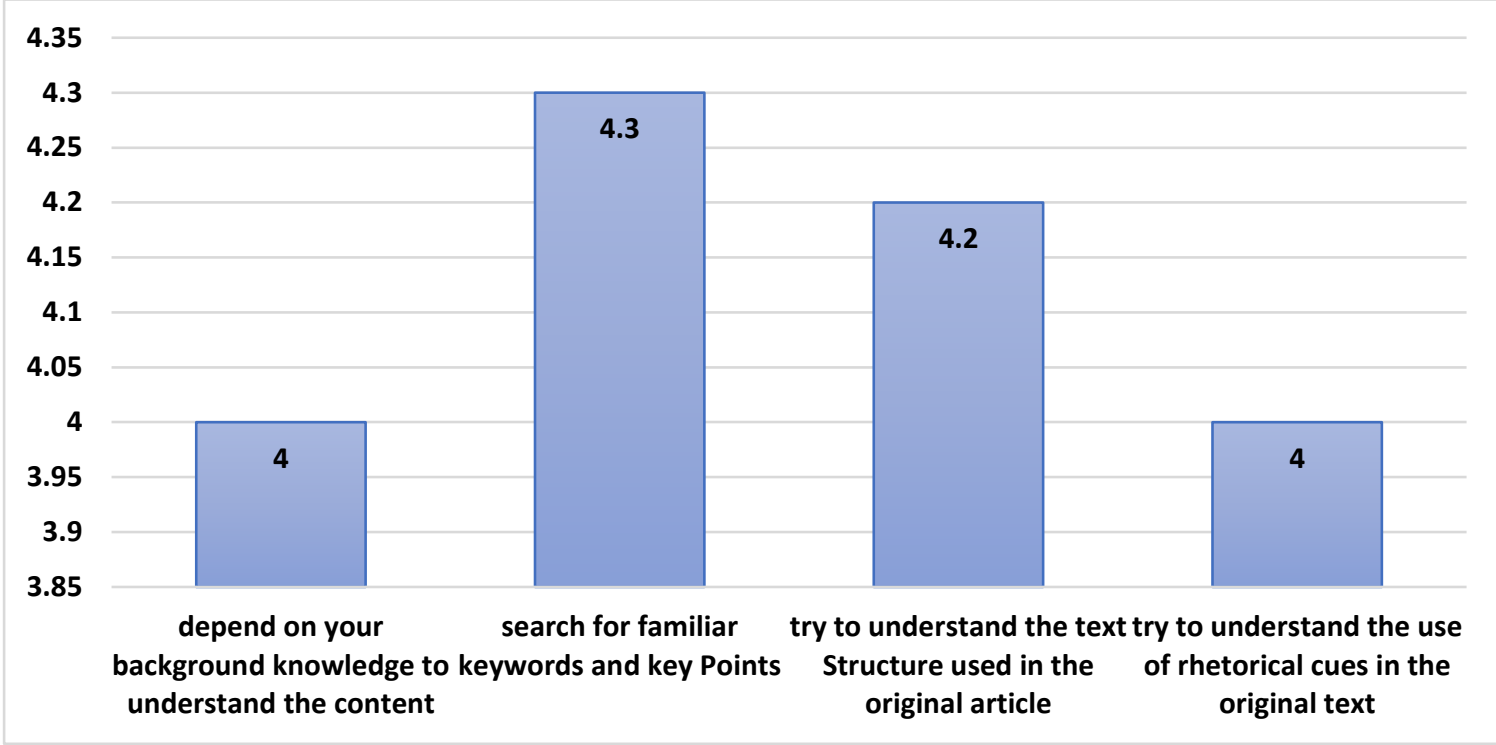

Figure 4-Bar Chart showing frequency for Background

With reference to Figure 4, respondents reported that they searched for "familiar keywords and key points" (4.3) and they tried to "understand the text structure used in the original text".

\subsubsection{Retrieval}

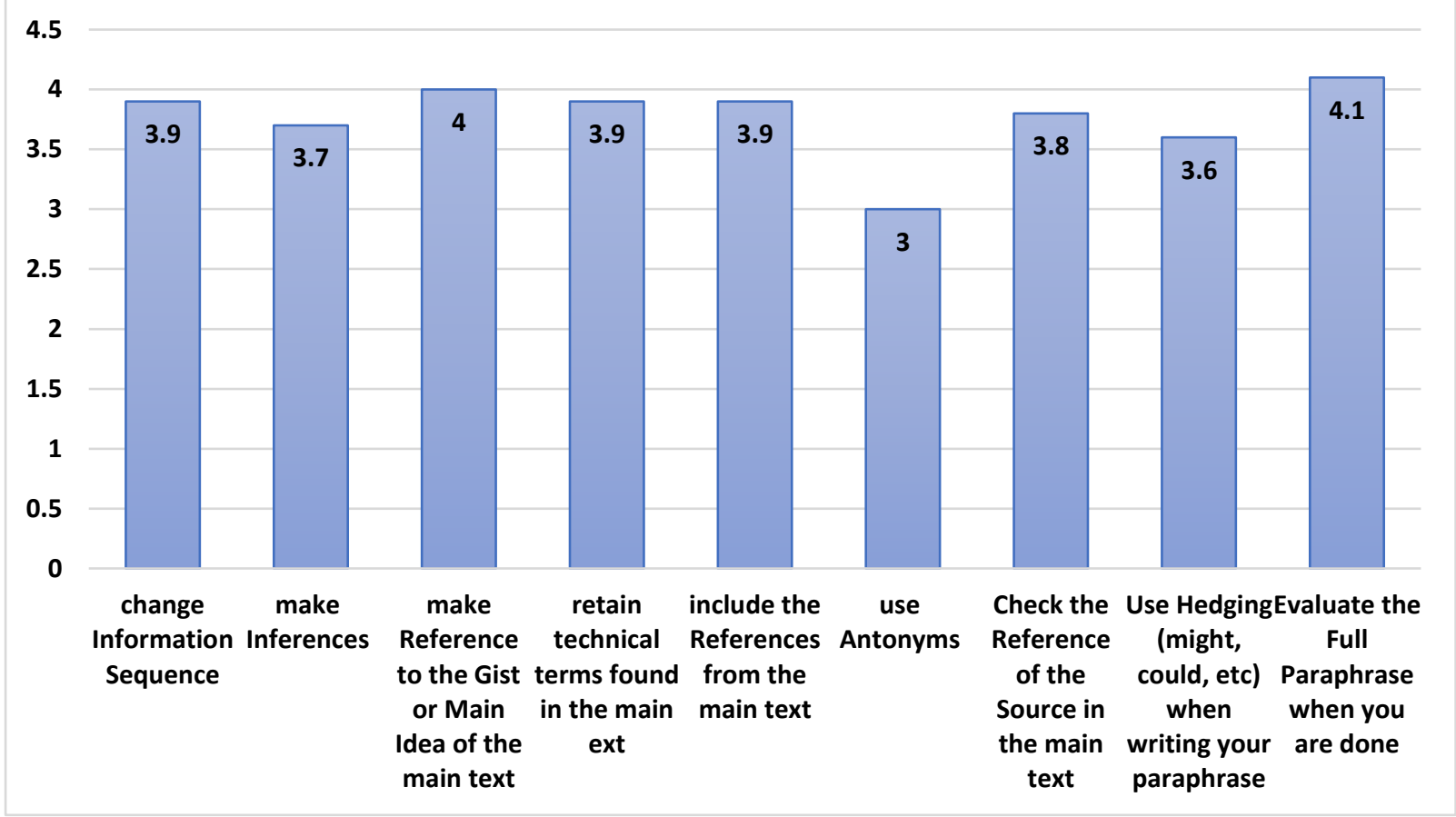

Figure 5- Bar Chart showing Frequency of Retrieval 
With reference to Figure 5, the respondents reported that they made "reference to the gist or main ideas of the main text" (4) and evaluated "the full paraphrase when" they are done paraphrasing (4.1).

\subsection{Metacognitive}

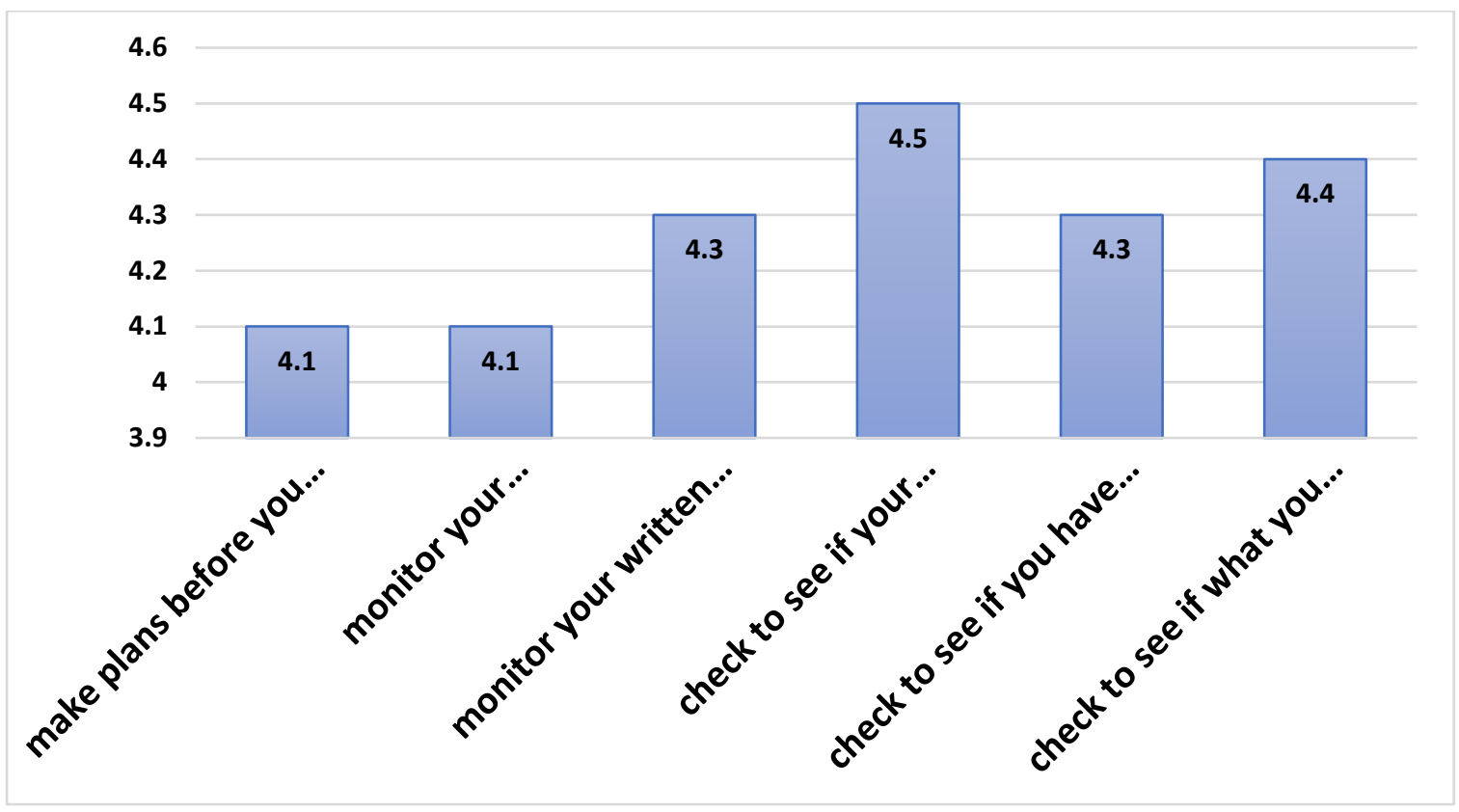

Figure 6- Bar Chart showing frequency for Metacognitive

Figure 6 shows the frequency for meatcogniitve strategies. Findings revealed that the respondents checked "to see if their paraphrases text looked alright" (4.5), checked "to see if they have paraphrased correctly" (4.4).

\section{Conclusion}

\section{Summary of Findings and Discussion}

Paraphrasing is not an easy activity for many writers. According to Bejos(2009) several factors make paraphrasing difficult. The difficulty arises from the writer's content knowledge, language skills and even structural skills. Another reason that makes paraphrasing difficult is that it is considered a read-to-write (Rahmat, 2020) process.

Nevertheless, the teaching of some types of paraphrasing strategies has helped writers ease the process. The use of cognitive and metacognitive strategies have been found to guide writers in the paraphrasing process. The findings in this study revealed that academic writers use both cognitive and metacognitive strategies to paraphrase. The study by Khrismawan and Widiati (2013) also found that paraphrasing activities involve the use of cognitive and metacognitive strategies. The combination of the two types of strategies facilitates academic writers in the paraphrasing process.

Although paraphrasing is a writing activity, it truly requires the writer to use both reading and writing skills to produce good paraphrased writing. The findings in this study found that writers used cognitive skills such as comprehending the original text, making connections to background, and also retrieving information. Sethuraman and Radhakrishnan (2020) reported 
that cognitive strategies help students to process, transform, and create information in order to assist writers to use language effectively in the knowledge acquisition process. It is also reported in this study that academic writers planned, monitored and checked their writing. These metacognitive strategies are also reported to be evident in the study by Aripin and Rahmat (2021) who also found that these metacognitive strategies facilitated academic writers in their overall paraphrasing plan

\section{Implication of Study}

Paraphrasing is not easy as it involves many levels of skills. Many take the short cut by "cutting-and-pasting" chunks of sentences from the original text. Some "play safe" by looking for synonyms to replace as they go along. Writing is a thinking process. It involves the writer to think BEFORE, WHILE AND AFTER the writing process. "Before" requires the writer to read the original text to be used to support his/her write-up. "During" demands that the writer goes back and forth to check on content, language use, and even arguments as the writing progresses. "After" is a reminder to the writer that when the write-up is completed, that only means the FIRST draft is completed-the next stage is- to go through many cycles of drafts.

\section{Suggestion for Future Research}

It is suggested that future research look into the thinking process of the writer to explore what goes in the mind of the writer when he/she is paraphrasing. A case study using think aloud protocol could be carried out to explore the thinking process of a writer going through what happens before, during and after writing.

\section{Contribution}

Findings of this study presents both theoretical and contextual contributions towards the knowledge on paraphrasing. Theoretical foundations on paraphrasing thus revealed the delicate process of paraphrasing that writers go through. The theoretical foundation formed in this study helped future research trace back to the roots of why paraphrasing skills are difficult for writers. The conceptual framework presented in this study carefully compartmentalize paraphrasing as both cognitive and metacognitive strategies. Knowing that paraphrasing strategies are both cognitive and metacogitve skill helps future researchers and writing teachers to plan (a) future teach writing activities based on cognitive and metacognitve skills and (b) to check on what writers lacked so teachers can focus on the remedy to take place as soon as the problem is detected.

\section{References}

Abdulkareem, M. (2013). An investigation study of academic writing problems faced by Arab postgraduate Students at Universiti Teknologi Malaysia (UTM). Theory and Practice in Language Studies, Vol 3 (9), pp 1552-1557.

Al Badi, I. (2015). Academic writing difficulties of ESL learners. In the 2015 WEI International Academic Conference Proceedings. Spain, Barcelona.

Al-Khasawneh, F. (2010). Writing for academic purposes: problems faced by Arab postgraduate students of the college of Business, UUM. ESP World, 9 (2), 1-23. Retrieved February 24, 2017, Retrieved from http:// www.esp-world.info.

Akbar, M. T. (2020) Students' Paraphrasing Skill in the Literature Review Section of Research Proposal. Jambura Journal of English Teaching and Literature, Vol 1(1), pp 1-15. 
Aripin, N., \& Rahmat, N. H. (2021) Metacognitive Writing Strategies Model used by ESL Writers in the Writing process: A Study across Gender. International Journal of Asian Social Science, Vol 1191), pp 1-9. Retrieved from http://doi.org.//10.18488/journal.1.2021.111.1.9

Bejos, K. (2009) Instruction in cause and Effect Paraphrasing Using Social Studies Text with a Secondary Bilingual Student: A Case Study. Perspectives on Communication Disorders and Sciences in Culturally and Linguistically Diverse (CLD) Populations, Vol 16(2), pp 5463. Retrieved from http://doi.org. 10.1044/cds16.2.54

Fish, R., and Hura, G. (2013) Students' perceptions of Plagiarism. Journal of the Scholarship of Teaching and Learning, Vol 13(5), pp 33-45. Retrieved from https://files.eric.ed.gov/fulltext/EJ1017029.pdf

Gilmore, B. (2008). Plagiarism: Why it Happens, How to Prevent it. Portsmouth: Heinemann. Gusparia, A. (2017) Students' Ability in Paraphrasing Paragraphs of English Study Program PKIP UNRI. Journal of English Education, Vol 13(1), pp 91-6. Retrieved from

Haron, H., Rahmat, N. H. (2020) Exploring the Theory of Activity in English Language Writing: The Case for Whatsapp. International Journal of Asian Social Science, Vol 10(11), pp 671684. Retrieved from http://doi.org/ 10.18488/journal.1.2020.1011.671.684

Hayuningrum, H., Yulia, M. F. (2017) Students' problems in Writing Paraphrases in Research Paper Writing Class. LLT Journal, Vol 15(1), pp 113-147. Retrieved from https://ejournal.usd.ac.id/index.php/LLT/article/download/296/251

Keck, C. (2006) The Use of Paraphrase in Summary Writing: A Comparison of L1 and L2 Writers. Journal of Second Language Writing, Vol 15(4), pp 261-278. Retrieved from http://doi.org/ 10.1016/j/jslw.2006.09.006

Khrismawan, B., and Widiati, U. (2013) Students' perception about Paraphrasing and their Cognitive Processes in Paraphrasing. TEFLIN Journal, Vol 24(2), pp 135-158. Retrieved from http://journal.teflin.org/index.php/journal/article/view/162

Larenas, C. D., Leiva, L. R., Navarrette, M. O. (2017) Rhetorical, metacognitive, and Cognitive Stratgeies in Teacher Candifdates' Essay Writing. PROFILE, Vol 19(2), pp 87-100. Retrieved from https://files.eric.ed.gov/fulltext/EJ1147222.pdf

$\mathrm{Mu}, \mathrm{C}$. (2005). A taxonomy of ESL writing strategies. Paper presented at the In Proceedings Redesigning Pedagogy: Research Policy Practice.

Na, C. D., and Mai, N. X. N. C. (2017) Paraphrasing in Academic Writing: A Case Study of Vietnamese Learners of English. Language Education, Vol 8 91), pp Retrieved from http://dx.doi.org/10.5746/LEiA/17/V8/I1/A02/Na_Ma

Rahmat, N. H. (2020) Knowledge Transforming in Writing: An Analysis of Read-to-Write process. European Journal of English Language Teaching, Vol 5(4). Pp 1-7. Retrieved from https://oapub.org/edu/index.php/ejel

Rahmat, N. H. (2019). Problems in Rhetorical problems among Academic Writers. American Journal of Social Sciences and Humanities, Vol4(4), pp 506-515Retrieved from http://doi.org/10.20448/801.506.515

Sedhu, D., Lee, M., and Choy, S. (2013). The Influence of Teaching Strategies on Students' Paraphrasing Strategies: A Case Study. International Journal of Independent Resaerch and Studies, Vol 2(3), pp 130-137. Retrieved from https://papers.ssrn.com/sol3/papers.cfm?abstract_id=2306219 
INTERNATIONAL JOURNAL OF ACADEMIC RESEARCH IN BUSINESS AND SOCIAL SCIENCES

Vol. 11, No. 3, 2021, E-ISSN: 2222-6990 @ 2021 HRMARS

Sethuraman, M., and Radhakrishnan, G. (2020) Promoting Cognitive Strategies in Second Language Writing. Eurasian Journal of Educational Resaerch, Vol 88(2020), pp 105-120. Retrieved from http://www.ejer.com.tr 